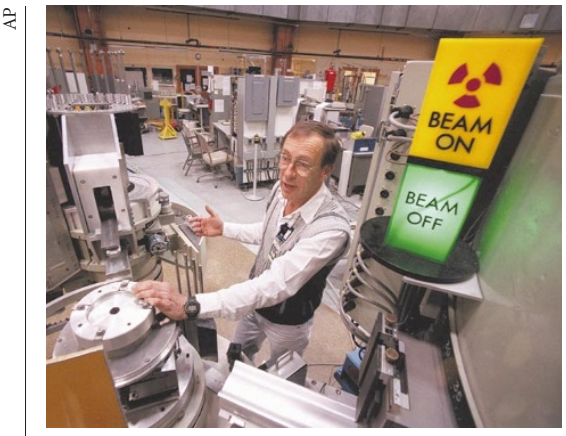

Off for good: the High Flux Beam Reactor.

- Richardson's decision was based on the advice of programme managers, who included Patricia Dehmer, senior staff official in charge of basic energy sciences, and Martha Krebs, head of the energy department's Office of Science. They recommended against continuing to spend \$20 million a year to keep the facility on standby.

"He got the recommendation of a termination, and on that day he made the decision," says Moniz. He points out that Brookhaven will remain one of very few laboratories housing two major scientific facilities, the Relativistic Heavy Ion Collider and the National Synchrotron Light Source.

Environmental groups have been pressuring the Department of Energy to close the reactor since the leak was discovered, even though the total amount of tritium discharged is less than that contained in an emergency exit sign in a cinema.

Opponents of the reactor were able to build on powerful anti-nuclear sentiment on Long Island. Construction of a nuclear power plant there was aborted after residents argued that the densely populated island could not be evacuated in an emergency.

The Department of Energy responded to the leak by firing the consortium of universities that had operated the laboratory. The new contractor had been making some progress in improving its relations with the laboratory's critics in the community (see Nature 400, 303; 1999).

But Michael Forbes, the local congressman, who recently switched from Republican to Democrat, has opposed the restarting of the reactor and has inserted language in appropriations bills for three years in a row expressly prohibiting it. Whatever Brinkley and Baldwin told Richardson, the energy secretary must have concluded that the department could no longer afford to spend an annual \$20 million maintaining an ageing facility that local politicians would not allow to reopen.

Colin Macilwain

\title{
Science lobby 'ecstatic' after triumph in NIH budget battle
}

\section{Washington}

The US National Institutes of Health (NIH) last week secured a 14.7 per cent increase in its budget for next year, achieving a remarkable triumph after an arduous congressional budget battle. The decision raises the biomedical agency's budget for the fiscal year 2000 to $\$ 17.9$ billion.

The House of Representatives and the Senate approved the increase just before adjourning for the year after weeks of struggle with the White House over budget priorities. The sum was part of a $\$ 385$ billion, 'omnibus' spending bill that combined five of the 13 bills funding the government.

Congress also last week approved a fiveyear extension to the research and development tax credit, which creates incentives for private industry to fund research projects.

The $\$ 2.3$ billion in new NIH funding, which keeps the agency on track for doubling its budget in five years starting this year, comes with two strings attached. The agency must wait until next 29 September, the end of the fiscal year, for $\$ 3$ billion of the overall budget. This is a budgetary device employed by Congress to allow it to appear to avoid spending Social Security revenues.

The NIH plans to handle the problem with 'split funding' — giving investigators part of their award at the time it is granted, and paying the remainder at the end of the fiscal year. Advocates see this as a big improvement on an earlier proposal that would have delayed $\$ 7.5$ billion in $\mathrm{NIH}$ funding to late September, and forced the postponement of new grants until then.

The $\$ 3$ billion deferral is "something that we can cope with," says David Kaufman, president of the Federation of American Societies for Experimental Biology (FASEB) and a professor of pathology at the University of North Carolina at Chapel Hill.

In addition, the NIH, like other federal agencies, is expected to be subject to a 3.8 per cent across-the-board spending cut insisted on by Republicans as a symbol of fiscal austerity. This would slice $\$ 68$ million from NIH's budget, lowering its effective increase to $\$ 2.23$ billion, or 14.3 per cent. But the loss is not definite, as the bill allows the president to exempt certain agencies from cuts.

Such provisos were insufficient to dampen the enthusiastic reaction of research advocates. They said last week that the NIH had pulled off a tremendous coup in wresting such a large increase from a budget maelstrom that saw Republicans fighting to find budget savings in all conceivable areas.

"It's an outstanding outcome. We're just ecstatic," says Tim Leshan, director of public policy at the American Society for Cell Biology. Considering that there were those in Congress who felt that the increase "was just too much too fast," the new money is "a tremendous victory," adds Mike Stephens, a FASEB lobbyist.

The bill includes a $\$ 45$ million increase in the NIH budget for the construction of extramural facilities, taking it to $\$ 75$ million. University administrators and NIH officials had been complaining that the agency's budget was insufficient for what they describe as the decaying infrastructure of US biomedical research facilities (Nature 399, $621 ; 1999$.

Meredith Wadman

\section{Hughes institute unveils top team}

\section{Washington}

The Howard Hughes Medical Institute (HHMI), the largest biomedical research charity in the United States, has appointed a management team that is expected to shake up the institute's portfolio in the new year.

Gerry Rubin, a geneticist at the University of California at Berkeley, will join the institute on 1 January as vice-president for biomedical research. He will team up with David Clayton, who will become vicepresident for science development.

The two appointments were announced last week by Tom Cech, the University of Colorado Nobel laureate who takes over as president of the HHMI in January. Cech said the appointments to replace Max Cowan, the institute's retiring scientific director, signalled the expanding scope of its activities.

"Max is irreplaceable, so we've decided to divide things up a bit differently," says Cech, adding that the decision reflects the continuing expansion of the institute's portfolio. "If we just planned to maintain what we have, we wouldn't need two people."

The HHMI's annual expenditure has grown rapidly in recent years, from around $\$ 300$ million in 1994 to more than $\$ 500$ million last year, as the stock-market boom has fed an endowment now worth some $\$ 10$ billion. Four-fifths of the expenditure supports an elite of 300 salaried investigators - all biomedical scientists at US universities with the rest distributed as grants for under- 
- graduate and postgraduate education, and for research overseas.

Cech says Rubin will take over supervision of the investigators, while Clayton will be responsible for "strategic planning" of the institute's activities. Clayton is currently a senior scientific officer at the HHMI and was formerly associate director of the Beckman Center at Stanford University in California.

Rubin will maintain his laboratory at Berkeley, although it will contract sharply once it has completed its current project to sequence the genome of the fruit fly Drosophila in collaboration with Celera (see Nature 401, 729; 1999).

"I've felt for a while that it is time to take on a more administrative role," he says. "I enjoy policy, and this is the ideal job because you don't have to worry about where the money's coming from."

Cech is also keeping his laboratory at the University of Colorado. Both Rubin and Cech plan to spend about 20 per cent of their time on research.

Although all three say that no decisions have been made about new directions at the HHMI, Cech suggests that the institute will explore new ways of encouraging top-quality clinical research in the United States, and is likely to build on plans already announced to appoint investigators in bioinformatics.

But they expect that such decisions will be
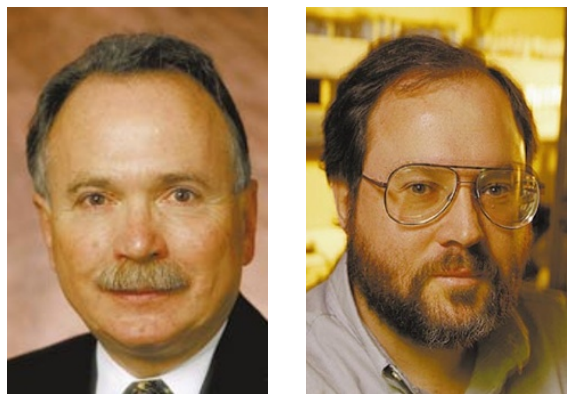

Clayton (left) and Rubin: expected to shake up management of the largest US medical charity.

made quickly once they take over operation of the institute in January. "I don't know what will be announced, but I'd hope that the first year of the administration will be an interesting one," says Clayton.

Cowan, who has steered the institute's scientific programmes with an iron hand for the past 12 years, says he plans to pursue his keen personal interest in the history of neuroscience during his retirement.

Purnell Choppin, the outgoing president, will remain at the HHMI's headquarters at Chevy Chase, Maryland, writing an official history of the institute. There are conflicting views as to whether the institute's secretive and eccentric billionaire founder set it up primarily as a medical research institute or a tax dodge.
Busquin plans white paper to integrate European research

\section{Brussels}

The European Union's (EU) new research commissioner, Philippe Busquin, has promised to publish a white paper (policy document) early next year outlining his plans for the creation of a European Research Area (see Nature 401, 837; 1999).

Speaking to a meeting of the European Parliament's committee on industry, external trade, research and energy, Busquin said that the paper will address issues such as how to achieve mobility of researchers across the EU, whether researchers' careers should have a 'European dimension', and how to "stimulate the taste for research among the young and promote the participation of women in science".

Busquin told the committee that he wanted to raise the total research and development spending of EU member states from its current level of 1.8 per cent of gross domestic product towards the 2.8 per cent of the United States and the 3 per cent of Japan.

Keith Nuttall

\section{Genentech pays \$200m over growth hormone 'theft'}

San Diego

The biotechnology company Genentech last week agreed to pay $\$ 200$ million to settle a patent infringement lawsuit, over the alleged use of human growth hormone DNA taken 20 years ago from the University of California at San Francisco (UCSF).

The settlement - the largest such payment in a biotechnology case — ends a federal lawsuit that has exposed a seamy side to the relations between universities and industry at the dawn of the biotechnology era.

The university sued Genentech nearly a decade ago, claiming that a midnight 'theft' in 1978 of growth hormone DNA was key to the firm's development of its blockbuster growth-hormone drugs. The company acknowledged receiving the growth hormone DNA, but insisted that it was not used to produce its drugs.

About $\$ 85$ million of the settlement will be split equally between three inventors formerly at UCSF - Peter Seeburg of Germany, John Shine of Australia and Howard Goodman of Harvard University and two collaborators, John Baxter of UCSF and Juan Martial of Belgium.

The settlement also includes a Genentech

NATURE | VOL 402 | 25 NOVEMBER 1999 | www.nature.com contribution of $\$ 50$ million towards the construction of a research building on UCSF's developing Mission Bay Campus. Genentech has the right to name the building, which will cost $\$ 235$ million. The remaining \$65 million will go to the university and UCSF.

UCSF Chancellor Michael Bishop says that the settlement "was negotiated in an amicable manner out of mutual respect. The relationship between these two institutions in the past has been collegial and historic. Now, we can continue in the same spirit." A joint statement by the university and the company noted that the settlement is not an admission of patent infringement.

Arthur Levinson, Genentech's chairman and chief executive, said that the company "has decided to put this matter behind us and avoid the distraction and uncertainty of another jury trial covering complex patent issues that are based on events that took place nearly 20 years ago". Genentech will take the $\$ 200$ million as a one-time expense during the next quarter, he said.

Last June, in the eyes of many observers, the university nearly won its demand for $\$ 400$ million in damages, which it sought to have tripled because of Genentech's conduct.
After a six-week trial, eight of the nine jurors found that the university's patent had been infringed (see Nature 399, 512; 1999), but a unanimous verdict was required. This set the stage for a retrial, scheduled for January.

Seeburg, who is now at the Max Planck Institute for Medical Research in Cologne, remains under investigation for possible scientific misconduct 20 years ago. At last spring's trial, Seeburg testified about how he took the growth hormone DNA from UCSF to Genentech, where he had gone to work after leaving UCSF.

The UCSF DNA was used to produce Genentech's drug, he testified, and a Nature article in 1979 (see Nature 281, 544-548; $1979)$ contained "technical inaccuracies" which effectively disguised Genentech's use of the UCSF DNA. This testimony prompted the ongoing probe.

UCSF officials acknowledged last week that the investigating German authorities have requested assistance, adding that the university is in the process of responding. Contacted in Germany, Seeburg said that he was "very relieved" about the settlement, although he denied that he had been required to contribute towards the legal costs incurred. Rex Dalton \& Quirin Schiermeier 